\title{
Regulation for Providing Medical First Aid/Medical Care on Board Ferry Vessels in Croatia: Update Proposal
}

\author{
Luka Vukić, Rosanda Mulić, Ivan Peronja, Merica Slišković
}

The Republic of Croatia is a leader in maritime passenger transport in the Adriatic with indications of the further growth. The paper analyses current regulations for providing medical care on board vessels in Croatia for the category C2 of navigation, referring to vessels in the national coastal navigation. The prescribed quantities of medicinal products and equipment on ferry vessels were compared with the data of most common diseases and injuries of passengers on board, retrieved from the relevant literature. The comparison was conducted based on two indicators: the frequency and urgency of diseases and injuries. The analysis indicated the insufficient quantity of medicines and equipment, especially in the cases of life-threatening medical conditions. The regulations should follow the growing maritime passenger transport, where the large inflow of passengers is

\section{KEY WORDS}

$\sim$ Croatia

$\sim$ Ferry vessels

$\sim$ Medical care

$\sim$ Passenger transport

$\sim$ Regulation

University of Split, Faculty of Maritime Studies, Split, Croatia

e-mail: luka.vukic@pfst.hr

doi: 10.7225/toms.v07.n02.009

This work is licensed under (cc) BY expected regularly in the summer period. All the personnel on board appointed for the provision of medical care are required to provide immediate treatment, increase the level of preparedness, and improve the prevention of possible health risks onboard vessels. The authors want to emphasize the importance of passenger safety on board as well as the preservation of strategic resource for the Croatian economy.

\section{INTRODUCTION}

Croatia is a maritime country with a long tradition and a hundred of islands connected with shore and major coastal areas by ferries, passenger ships, hydrofoils, and catamarans. This means of transport, especially ferries, are essential for the 124,955 residents on the inhabited Croatian islands. According to the Croatian Bureau of Statistics, 30.9 million of passengers were transported by ferries and passenger ships in 2017 with the tendency of continuous increase. The state-owned company is responsible for the maintenance of a vast majority of shipping lines towards the islands and with the fleet of 50 vessels makes $80 \%$ of the total of transported passengers and vehicles in the maritime transport of the country.

With the accession of the Republic of Croatia to the European Union, the Directive 92/29/EEC, regarding the medical treatment on board vessels was transposed in the Croatian national legislation in the form of Ordinance on the minimum requirements and conditions for providing medical care on board vessels, boats, and yachts. The increase of passenger transport in the Croatian ports is not accompanied with the necessary 
modifications of the Ordinance especially in the part that regulates the category of national coastal navigation. It appears that for this category of navigation the Ordinance prescribes currently insufficient medical equipment for provision of medical assistance in serious, life-threatening cases that are, according to total number of passengers, possible and expected on board particularly in summer periods. This is manifested in the absence of the basic equipment or, more precisely, the equipment for resuscitation and transport immobilization. With the existing Ordinance the risk of potential fatal consequences increases as well as the creation of negative public image and distrust of the users as participants in the transportation chain in the event of an accident. Regarding potential injuries, the Ordinance provides only a set of stop bleeding (hemostasis) and wound bandaging. Bearing in mind a number of potential, different medical conditions that could happen to passengers in the current circumstances, the Ordinance should be analyzed. The analysis of maritime passenger transport in Croatia and existing Ordinance aims to improve passenger safety, quality of traffic service, and safety of navigation.

\section{ANALYSIS OF THE MARITIME PASSENGER TRANSPORT IN CROATIA}

Maritime passenger transport is an important segment of passenger transport on a global scale, and in that form often neglected in the scientific literature (Stupalo et al., 2016). It is divided into cruise and non-cruise modalities, of which the latter refers to passengers transported by ferry vessels. The characteristics of ferries are manifested on relatively short distances and liner services (Holt et al., 2017). The global ferry industry transports yearly around 2.1 billion passengers with additional 250 million vehicles and 32 million trailers (InterFerry, 2018). According to the research carried out by Martino and Brambilla, the Mediterranean is the dominant region in Europe regarding the share of passenger volumes on ferries (Maritino and Brambilla, 2016), as shown by Figure 1.

\section{Passengers traffic volumes in the EU regions (in thousands)}

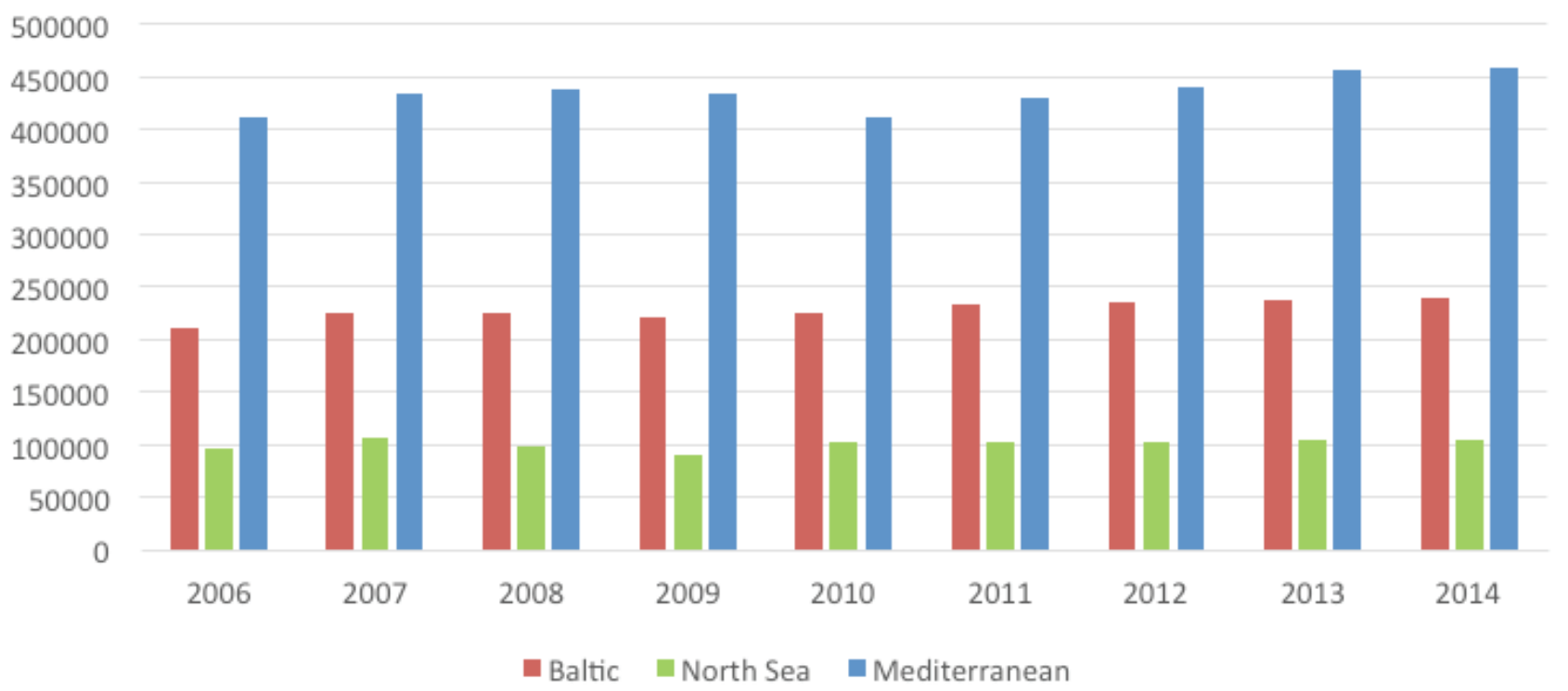

Figure 1.

Passenger traffic volumes on ferry vessels in the EU regions (in thousands) (Maritino and Brambilla, 2016).

The Mediterranean, a leader in the ferry traffic in Europe, recorded a $56 \%$-share or $464,972,769$ of the total of 830 million passengers transported in Europe by ferry ships in 2017 (Holthof, 2017).

The Republic of Croatia surpassed the share of $18 \%$ of GDP from tourism income in 2015 (Croatian Chamber of Economy,
2017). One of the essential segments both for tourism and the development of the inhabited islands is maritime passenger transport, which recorded a total traffic of 32.5 million passengers in the Croatian seaports in 2017. Table 1 shows the national traffic increase of $5.77 \%$ with regard to 2016 (Croatian Bureau of Statistics, 2018) 
Table 1.

Passenger traffic in Croatia, various modes (Croatian Bureau of Statistics, 2018).

\begin{tabular}{|c|c|c|c|}
\hline Year & Traffic of passengers in total & $\begin{array}{l}\text { National traffic of } \\
\text { passengers }\end{array}$ & $\begin{array}{l}\text { International traffic of } \\
\text { passengers }\end{array}$ \\
\hline 2013 & $28,791,287$ & $26,938,838$ & $1,852,449$ \\
\hline 2014 & $24,710,914$ & $22,981,095$ & $1,729,819$ \\
\hline 2015 & $28,513,365$ & $26,837,904$ & $1,675,461$ \\
\hline 2016 & $30,983,336$ & $29,235,931$ & $1,747,405$ \\
\hline 2017 & $32,523,201$ & $30,921,981$ & $1,601,220$ \\
\hline
\end{tabular}

The importance of ferry transport in Croatia is manifested in the direct economic impact of the Croatian shipping industry and its contribution to the GDP. In 2016, it exceeded 1.2 billion HRK (Croatian Kuna), where ferry transport contributed with more than $30 \%$ of total direct impact and directly employed more than $30 \%$ of employees within the shipping sector in Croatia (Oxford Economics, 2017).

The vast majority of maritime liner transport routes in Croatia are managed by the state-owned company, which surpassed over 11.8 million passengers and 2.9 million vehicles transported in 2017. The company dominated both segments of transport in 2017 leading the market with the share of $87 \%$ of the total passenger transport and $89.8 \%$ of vehicle transport (Costal Liner Service Agency, 2018). The coastal line passenger transport enables permanent and efficient connection of the islands and coast (Ministry of the Sea, 2017), especially important for the inhabitants deeply relying on the ferry (liner) and catamaran service in everyday life.

The study realized by Risposte Tourismo indicates ferry transport as a valuable means of transport regarding the geographical structure of the Adriatic. It also demonstrates the significance of ferry, hydrofoil and fast catamaran traffic for the Croatian ports, marked as the overall leaders in the Adriatic in the segments of passenger movement as well as the number of the port of calls in 2016. Croatian ports retained over $50 \%$ of passenger movement in the Adriatic, almost half of the overall number of passengers, and $57 \%$ of ports of call, maintaining the positive trends over the recent years. The forecasts in the Adriatic and the Croatian ports are positive, so further increase is expected in the future (Risposte Tourismo, 2017).

\section{ANALYSIS OF THE CURRENT REGULATIONS REGARDING MEDICAL CARE ON VESSELS IN CROATIA (FERRIES AND PASSENGER SHIPS)}

The existing Ordinance on the minimum requirements and conditions for providing medical care on board vessels, boats and yachts is the main document on the national level in Croatia which prescribes minimum requirements onboard vessels, equipment and devices for the provision of adequate medical care both to crew members and passengers and minimum contents of the ship's pharmacy as well as a form and manner of keeping prescribed records (Ministry of the Sea, Transport and Infrastructure, 2008). All maritime officers in the merchant marine, including the crew, operating on passenger ships are required to possess the proper certificates prescribed by the International Convention on Standards of Training, Certification, and Watchkeeping for Seafarers (STCW), some of them mandatory, comprising the certificate of Medical First Aid (STCW VI/4-1) (Mulić et al., 2012). The possession of required certificate indicates the confirmation of completed specific education to perform medical health assistance. Furthermore, masters and officers of higher rank and other crew members who are responsible to provide medical care on board ships are required to possess Medical Care Certificate (STCW VI/42 ), depending on the function(s) and level of responsibility on board. These responsibilities are assigned in practice to officers on deck (first or second officer) designated by the master (Goethe, 1984), having a responsibility in assisting the master in case of injury or another emergency in the provision of medical care both to crew members and passengers onboard (Marine Colleges, 2017). Usually, the 2 nd officer is responsible for medical care on board, delegated by the master (Westlund et al., 2016). The proper education and preparedness of the crew members in the provision of medical care on board vessels in emergency are essential for the safety of passengers and crew, especially the ones operating on ferries and passenger ships, given the fact that, unlike cruise ships, they are not required to possess a sick bay or ship's hospital if they are engaged for a voyage of fewer than three days (European Economic Community, 1992). All officers are required to refresh the medical courses every 5 years (Jensen et al., 2005).

The Ordinance recognizes four categories of navigation A1 (Unrestricted navigation), B (Long coastal navigation), C1 (Short 
coastal navigation, Coastal navigation along the Adriatic, National navigation) and C2 (National coastal navigation, National inshore navigation, Local navigation), where categories C1 and C2 are implied for the ferry transport between islands and shore. It is evident that ferries and passenger ships operating in the coastal line passenger transport belong to the categories $\mathrm{C} 1$ and $\mathrm{C} 2$ of navigation, referring to the "National navigation" and "National coastal navigation". As the "National coastal navigation", category $\mathrm{C} 2$, is the dominant segment of ferry transport, related to the vessels navigating in the national coastal navigation in the internal waters of the Republic of Croatia and waters accessible from the sea (Ministry of the Sea, Transport and Infrastructure, 2006), only vessels in this category and the minimum requirements and quantities of medicines and medical equipment on vessels will be analyzed. The Directive 92/29/EEC issued by the Council of the European Union in 1992 provides guidelines for each category of navigation and the Member states, determines a detailed list of minimum requirements on the provision of the medical care on ships, divided into ten annexes. Two annexes of the Ordinance are related to prescribing minimum amounts of medicinal products and medical equipment on ships and divided into main categories, followed by subcategories depending on the type of injury and disease, so for each vessel category, the prescribed quantity of medicinal products and medical equipment, as well as the contents of medical supplies are provided. The main categories of the prescribed medicines and medical equipment for each vessel category (A, B, C1, C2) are indicated in Table 2.

Table 2.

Main categories of prescribed medicines and medical equipment on board ship.

\section{MINIMUM AMOUNT OF MEDICINES ON BOARD SHIP (CATEGORIES)}

medicines for the cardiovascular system

gastro-intestinal system

analgesics and antispasmodics

preparations with the effect on the nervous system

anti-allergics and anti-anaphylactic

respiratory system medicines

anti-infection medicines

compounds promoting rehydration, caloric intake, and plasma expansion

medicines for external use

\section{MINIMUM AMOUNT OF MEDICAL EQUIPMENT ON BOARD SHIPS (CATEGORIES)}

resuscitation equipment

dressing and suturing equipment

instruments

examination and monitoring equipment

equipment for injection, perfusion, puncture, and catheterization

general medical equipment

immobilization and setting equipment

equipment for disinfection, disinsectization, and prophylaxis

first aid handbook

prescribed quantities. These amounts prescribed by the Ordinance for the navigation category $\mathrm{C} 2$ are presented in Table 3.

Table 3.

Prescribed minimum amounts of medicinal products by categories for navigation category C2.

\section{MEDICINAL PRODUCTS (CATEGORIES)}

Medicines for the cardiovascular system

Gastro-intestinal system

Analgesics and antispasmodics

Nervous system medicines

Anti-allergics and anti-anaphylactics

\section{RECOMMENDED QUANTITY (SUBCATEGORIES)}

Anti-angina preparations (one dose) I

Analgesics, antipyretic and anti-inflammatory preparations (one dose of paracetamol tablets)

Seasickness remedies (two doses)

/ 
Respiratory system medicines

Anti-infection medicines

Compounds promoting rehydration, caloric intake, and plasma expansion

Medicines for external use

\section{I}

I

/

Skin medicines

- antiseptic solutions (one dose)

- antibiotic ointments (one dose)

- anti-inflammatory and analgesic ointments (one dose)

Burn preparations (one dose)

Eye medicines

- antibiotic ointments and drops (one dose)

- diagnostics (one dose)

In order to ensure appropriate medical treatment at sea, the minimum required medical equipment on board vessels for the navigation category $\mathrm{C} 2$ is presented in Table 4.

Table 4.

Prescribed minimum amounts of medical equipment by categories for navigation category $\mathrm{C} 2$.

\section{MEDICAL EQUIPMENT (CATEGORIES)}

Resuscitation equipment

Dressing and suturing equipment

\section{RECOMMENDED QUANTITY (SUBCATEGORIES)}

/

- disposable polyethylene gloves (quantity 1)

- elastic bandages (various sizes; quantity 2)

- sterile gauze compresses (various sizes; quantity 3)

- triangular sling (quantity 2)

- cotton wool (quantity 1 )

- micropore adhesive dressings (quantity 1)

- adhesive elastic bandage (various sizes; quantity 3 )

- mesh (quantity 1)

- Elastoplast (quantity 5)

- vaseline gauze (quantity 3)

- Calico bandage (various sizes; quantity 5)

Instruments

Examination and monitoring equipment

Equipment for injection, perfusion, puncture, and

catheterization

General medical equipment /

Immobilization and setting equipment

Equipment for disinfection, disinsectization, and prophylaxis

First aid handbook /

/

/

\section{dissecting forceps and hemostatic clamps (quantity 1)}

/

/ 


\section{THE MOST COMMON DISEASES AND INJURIES OF PASSENGERS ON BOARD VESSELS}

There is not enough relevant research data either on the global or national scale on the typical passenger injuries and accidents on ferries and passenger vessels without ship's doctors aboard. Only a few authors dealt with the examination of injuries and accidents in ferry and passenger transport, mainly in the segment of tele-medical services onboard vessels. So for the purpose of this research, the analysis of the other segments of maritime passenger transport on the global scale, mainly cruise, will also be used to demonstrate the most common medical conditions based on which the importance of implementation of the adequate equipment and medicines on board ships will be proposed.

The research made by Holt et al. (2017) is the first research paper on medical emergencies and evacuations without doctors on two ferries during a 3-year period. The research findings showed a total of 169 persons, of which 14 crewmembers transferred for medical emergencies ashore mainly for the heartrelated symptoms (38.5\%). Some of the other symptoms with the need of a medical assistance were related to stroke (12.4\%), fracture (11.8\%), acute abdomen (9.5\%) and respiratory (7.1\%) related symptoms. The research indicated the patient transfer rate of 4.3 per 100,000 person-days from ferries to shore side medical facilities, and a total evacuation rate of 2.3 per 100,000 person-days. The authors also indicated the intention of navigation officers to examine the possibility of adding paramedics on smaller ferries operating on shorter crossings (Holt et al., 2017). The statistics of tele-medical service can be interconnected with the typical diseases and injuries on board ferries in the observed period. The data indicate the incidence of the need for radio medical (RM) assistance of 5.7 calls per one million passengers on tours at sea (Jensen et al., 2005). Based on the analysis of 156 passengers and 58 crew members, the most common were gastrointestinal, mental and nervous, and circulatory/respiratory system diseases with the share of $47 \%$. Angina pectoris was a major problem among passengers. Injuries suffered by passengers like fractures and multiple injuries typically happened by falling, slips and external causes. Also, the authors indicated that most passengers were left uninformed regarding the limited medical help on board ferry vessels. The medicine set contents were considered insufficient in some cases of emergencies (Jensen et al., 2005). Westlund et al. (2016) examined the same field in Sweden on the sample of 651 passengers on passenger ships. The most common were general and non-specific symptoms (22.2\%) followed by the symptoms of cardiovascular (16.5\%), gastrointestinal (15.8 $\%)$ and musculoskeletal system (13.7\%). The analysis also noted the main accidents of passengers, where the highest frequency was related to skin (77\%) and then followed by musculoskeletal
(75\%), neurological (42\%), general and unspecific (16\%), and digestive injuries (6\%). Vallé et al. (2010) examined cardiovascular diseases aboard ships during a two year period in France. They found 179 such cases, 86 patients were aboard passenger vessel, and 74 passengers among them. They indicated cerebrovascular accidents and myocardial infarction as medical, giving the overview of the French legislation regarding the medical supplies and tele-transmission devices on board which since 2007 prescribes the obligation of possession of material enabling telecardiology practice, i.e. ECG and defibrillator. They concluded that in the case of cardiovascular disease an effective and prompt response is required regardless of the infrequency of the disease on board ships (Vallé et al., 2010). The analysis of other available literature indicated the slips and trips, food poisoning, illness and psychological distress (Aequitas Legal, 2014) as well as burns, sprains and strains, broken bones, crash injuries, amputations (Maritime Injury Guide, 2018), as the main injuries onboard ferry and passenger ships.

The data of the most common passenger injuries and diseases on cruise vessels can also be used as a general indicator of passenger pathology. Although considered as incomparable with the ones coming from ferries and passenger ships, the frequency of passengers with emergency symptoms and similarity in most common injuries and diseases in this segment of navigation increases the importance of training to face them and the possession of adequate equipment for emergency cases. As for the cruise ships, the presence of the medical doctor on board is mandatory, which is not the case on ferries and passenger ships.

According to the research of Dahl (2010) on the passenger accidents and injuries on board, among the 633 injured on cruise ships during 3 years, the most frequent type of accidents were trips, slips, falls and hits (active and passive) which amounted to more than $75 \%$ of all the accidents. The most frequent type of injuries was related to open wounds, with the share of $83.2 \%$, and then contusions, sprains, and strains. The authors also indicated the importance of educated and competent medical personnel and equipment to enable treatment of illness or injury on board (Dahl, 2010). Some authors also dealt with the study of rates of illness of passengers and crew in the four year period at a Caribbean cruise port (Marshall et al., 2016). They concluded that the predominant types of illnesses of passengers were related to infectious diseases; mainly gastroenteritis followed by influenza with the common share of $93 \%$. Research of Schutz et al. (2014) determined the rate and patterns of passenger illness and injuries on expedition cruise vessels to the Antarctic in the six months period. The study resulted in the 530 consultations for active medical complaints. The most common diseases were motion sickness (27\%), infectious processes (23\%), injuries (14\%), and others. Cardiovascular events were also recorded but 
on rare occasions. Regarding the injuries, the vast majority were related to simple contusions, lacerations, and sprains (Schutz et al., 2014).

Cardiovascular problems reported during the two year period aboard cruise vessels off Florida were analyzed by Novaro et al. (2010), where 100 cardiovascular emergencies were recorded. The most common symptom was chest pain (50\%) and acute coronary syndromes (58 \%) as the principal diagnosis. The mean age was $66+/-14$ years (Novaro et al., 2010).

Peake et al. (1999) noted that $11 \%$ of their patients, passengers on cruise ships, had serious or potentially lifethreatening diagnosis, representing $0.4 \%$ of the total of 196,171 passengers.

Table 5 .

Most common symptoms, diseases, and injuries of passengers and crew on board by different authors (ferries, passenger ships, cruise ships).

\section{FERRIES AND PASSENGER VESSELS}

Holt et al., 2017

Westlund et al., 2016

Valle et al., 2010

Various literature (internet sources)

\section{MOST COMMON SYMPTOMS AND DISEASES}

\section{heart disorders}

stroke

abdominal pain

respiratory symptoms

pregnancy

\section{gastrointestinal}

mental and nervous

diseases of the circulatory

/respiratory systems-

angina pectoris

general and non-specific symptoms symptoms of the cardiovascular system symptoms of the gastrointestinal tract musculoskeletal system

examined only cardiovascular diseases

food poisoning

psychological distress

\section{TYPICAL INJURIES}

fractures

fractures 


\section{DISCUSSION}

The insufficient amounts of medical products and equipment, often justified with the presence of ambulance vehicle alongside ferry or medical professionals among the passengers, indicate only improvisation in the organization of medical care onboard. The criteria for the prescribed minimum amounts of medicines and medical equipment for any category of vessels should be the frequency of injuries and diseases that happen on board and emergencies irrespective of frequency. Comparing the data obtained about frequent injuries and diseases on ferry and cruise vessels with the prescribed medicines and medical equipment mandatory on board for the C2 category, it is evident that the Ordinance is insufficient with regard to both criteria. Growing passenger transport in Croatia with potential more frequent injuries and diseases on board vessels could deepen this gap. The data from tele-medical consultations prescribed by the Directive and designated to one of the centers onshore and personnel (doctors) trained to provide medical advice (European Economic Community, 1992) are an important indicator of the most common illnesses and injuries on board vessels. Taking into consideration the data of the frequency for radio medical (RM) assistance of 5.7 calls per one million passengers (Jensen et al., 2005) as well as the evacuation rate of 2.3 per 100,000 person-days (Holt et al., 2017), and comparing it with the Croatian seaport passenger transport quantity in 2017, that need could be expected and could be several times more frequent. Consequently, the provision of efficient medical care on board becomes a priority. Given the seasonal features of the Croatian tourism, number of passengers, and frequency of emergency calls, a call could be expected every day or every second day. The current Ordinance mostly prescribes medicines and equipment for non-life-threatening conditions. The distances in the national coastal navigation between ports are short and the passengers are appropriately disposed by emergency services on the coast in a short time period, usually within 2 hours. The recommended choice and quantity of medicines on board vessels for nonurgent medical conditions should correspond to the most common diseases on passenger vessels provided in the relevant studies, mainly related to the diseases of the gastrointestinal system, nervous system, and infectious diseases. They are not a real need in national coastal navigation. Cardiovascular diseases were also noted on board, but unlike others they can often be life-threatening. These diseases as well as allergic/anaphylactic reactions represent the priority in the provision of medical care requiring immediate treatment, so the prompt procedure and efficient utilization of medicines and medical equipment are needed to save life and reduce possible complications and consequences of the disease.
The most common injuries onboard passenger vessels are in the form of simple contusions and fractures from slips, hits, falls, and other external sources. The ship is a special environment and unforeseeable situations are expected, especially when a large inflow of passengers occurs, such as the case of the Croatian passenger transport in the summer periods. The current medical equipment consists only of the sets of stop bleeding and wound bandaging. There is a lack of basic equipment for transport immobilization and setting, referring to the most common injuries obtained by the data from previous studies. Sometimes, the accident results in head contusion and injury of the brain. It is a life-threatening condition and, as already mentioned above, there is no prescribed medical set for resuscitation.

Prescription of the equipment for resuscitation and transport immobilization as a standard for C2 vessel category increases the level of medical preparedness for serious cases as well as of passenger safety. The carriage of a portable defibrillator on board passenger vessels is also recommended, especially when the implementation of automated defibrillators (AED) in the crowded public places is supported by the European Union through various programs and projects (Ferretti et al., 2017). Also, some educative projects promoting the importance of defibrillation were launched in Croatia, but did not achieve the desired effect (Croatian Institute of Emergency Medicine, 2018).

Measures to increase health care on vessels in the $\mathrm{C2}$ category should not be based only on the prescription of equipment and medicines necessary for the prevention and assistance in the event of potential health complications on vessels. The recommendations are focused on the establishment of both Helicopter emergency medical service and Emergency fast boat medical service at sea with trained personnel and innovative technologies, drones for the delivery of medicines non-available on the scene of the accident to provide the necessary medical assistance to persons when characteristics of the disease or injury onboard exceed the possibilities of the crew and available equipment. The improvements are required in the segment of coordination between the existing emergency medical services at sea including the services of Search and Rescue and helicopters provided by the Ministry of Defense. Organization of the events in the port area once per year with the aim of raising citizens' awareness and education on the importance of providing basic medical assistance onboard vessels is proposed. Furthermore, personnel licensed to provide medical assistance on board vessels (Certificate of Medical First Aid and Medical Care Certificate) in national coastal navigation, masters and usually the 1 st or 2 nd deck officers, are recommended to have annual training for the improvement purposes of provision of medical care on board vessels provided by competent institutions. Finally, the Republic of Croatia should establish the 
Strategy for the development of emergency medical assistance in Croatia providing the guidelines and specific goals, and a vision of the development of this sensitive segment.

The ultimate aim is to indicate that the regulations of the Ordinance are not accompanied by an increase in the passenger transport in the Republic of Croatia as well as the need to preserve one of the crucial resources in Croatia, generators of tourism which creates multiple benefit effects. A clear and strong confidence developing within the land connection with islands and quality of transport to them could collapse in case of negative public image and dissatisfaction of transport users in case of potential accidents or death cases. That is why modification of the Ordinance is imposed as an obligation in order to emphasize the importance of human life and prevention of possible health risks on board vessels in the the eastern Adriatic.

\section{CONCLUSION}

The available evidence from other studies indicates a lack of the currently prescribed quantity of specific medicinal products and equipment considering both frequency and urgency of injuries and diseases as indicators of the need for specific medical care on board ferry vessels. The inclusion of equipment for resuscitation, transport immobilization, and portable defibrillator in an integral part of the $\mathrm{C} 2$ vessel navigation standard in Croatia represents a top priority in potentially life-threatening conditions. Studies on morbidity and mortality of passengers onboard ferry vessels in the Adriatic are necessary to make the findings more relevant.

\section{REFERENCES}

Aequitas Legal, 2014. Ferry Accident Claims, Accidents and injuries on ferries. Available at: https://www.aequitaslegal.co.uk/services/travel-claims/ferry-claims/, accessed: Feb 202018.

Costal Liner Service Agency, 2018. Traffic of passengers and vehicles in 2017. Available at: http://www.agencija-zolpp.hr/Portals/12/download/Promet_ putnika_i_vozila_2017.pdf, accessed on: Jan 222018.

Croatian Bureau of Statistics, 2018. Traffic in seaports fourth quarter of 2017. Available at: https://www.dzs.hr/Hrv_Eng/publication/2017/05-01-03_04_2017. htm, accessed on: Jan 222018

Croatian Chamber of Economy, 2017. Tourism in 2016. Available at: https://www. hgk.hr/documents/aktualna-tema-turizam-u-20165899d9633ad81.pdf, accessed on: Jan 152018.

Croatian Institute of Emergency Medicine, 2018. Projects: Start the Heart - Save a Life. Available at: http://www.hzhm.hr/pokreni-srce-spasi-zivot/, accessed Feb 26 2018.

Dahl, E., 2010. Passenger accidents and injuries reported during 3 years on a cruise ship, Int. Marit. Health, 61(1), pp. 1-8.

European Economic Community, 1992. Council Directive 92/29/EEC of 31 March 1992 on the minimum safety and health requirements for improved medical treatment on board vessels. Official Journal of the European Communities. Available at: http://eur-lex.europa.eu/legal-content/EN/TXT/PDF/?uri=CELEX:31992L0029\&fr om=EN, accessed on: Jan 222018

Ferretti, J., Di Pietro, L. \& De Maria, C., 2017. Open-source automated external defibrillator. HardwareX, 2, pp.61-70. Available at: http://dx.doi.org/10.1016/j.ohx.2017.09.001.

Goethe, W.H.G., Watson, E.N. and Jones, D.T., 1984. Handbook of Nautical Medicine, Berlin: Springer-Verlag.

Holt, T.-E., Tveten, A. \& Dahl, E., 2017. Medical emergencies on large passenger ships without doctors: the Oslo-Kiel-Oslo ferry experience. International Maritime Health, 68(3), pp.153-158. Available at: http://dx.doi.org/10.5603/imh.2017.0027.

Holthof, P., 2017. Mediterranean Ferry Update. Interferry Conference 2017. Available at: http://www.interferry.com/conference/2017-conference-papers/, accessed Jan 152018

InterFerry, 2018. Ferry industry facts. Available at: http://www.interferry.com/ communications/\%20ferry-industry-facts/?, accessed on: Jan 152018.

Jensen, O.C., Bo Bøggild, N. \& Kristensen, S., 2006. Telemedical Advice to LongDistance Passenger Ferries. Journal of Travel Medicine, 12(5), pp. 254-260. Available at: http://dx.doi.org/10.2310/7060.2005.12503.

Marine Colleges, 2017. Job responsibility of 2nd deck officer. Available at: http:// marinecolleges.com/job-responsibility-of-2nd-officer/, accessed on: Feb 92018.

Maritime Injury Guide, 2018. Ferry Accidents and Injuries. Available at: http:// www.maritimeinjuryguide.org/maritime-accidents-injuries/vessel-injuries/ferry/, accessed on: Feb 202018.

Marshall, C.A., Morris, E. \& Unwin, N., 2016. An epidemiological study of rates of illness in passengers and crew at a busy Caribbean cruise port. BMC Public Health, 16(1). Available at:

http://dx.doi.org/10.1186/s12889-016-2991-3.

Martino, A. and Brambilla, M., 2016. Research for TRAN Committee - The EU Maritime Transport System: Focus on Ferries. Brussels: EU.

Ministry of the Sea, Transport and Infrastructure, 2006. Decree on categories of navigation of sea-going ships. Narodne novine, 2006(46). Available at: https:// narodne-novine.nn.hr/clanci/sluzbeni/2006_04_46_1135.html, accessed on: Feb 20 2018.

Ministry of the Sea, Transport and Infrastructure, 2008. Ordinance on the minimum requirements and conditions for providing medical care on board vessels, boats, and yachts. Narodne novine, 2008(14). Available at: https://narodne-novine.nn.hr/ clanci/sluzbeni/2008_02_14_429.html, accessed on: Jan 282018.

Ministry of the Sea, Transport, and Infrastructure of the Republic of Croatia, 2017. Transport Development Strategy 2017-2030. Available at: http://www.mppi.hr/ UserDocsImages/MMPI\%20Strategija\%20prometnog\%20razvoja\%20RH\%20 2017.-2030.-final.pdf, accessed Jan 282018.

Mulić, R., Vidan, P. and Bošnjak, R., 2012. Comparative Analysis of Medical Assistance to Seafarers in the World and the Republic of Croatia. Book of Proceedings, The 15th International Conference on Transport Science. Faculty of Maritime Studies and Transportation, Slovenia.

Novaro, G.M. et al., 2010. Cardiovascular Emergencies in Cruise Ship Passengers. The American Journal of Cardiology, 105(2), pp. 153-157. Available at: http://dx.doi.org/10.1016/j.amjcard.2009.09.004. 
Oxford Economics, 2017. The economic impact of the Croatian shipping industry. London: Oxford Economics. Available at: http://csamarenostrum.hr/userfiles/files/ Economic\%20lmpact $\% 20$ of $\% 20$ the $\% 20$ Croatian $\% 20$ Shipping $\% 20$ Industry $\% 20$ vFINAL\%20v1.pdf, accessed on: Jan 282018.

Peake, D.E. et al., 1999. Descriptive Epidemiology of Injury and IIIness Among Cruise Ship Passengers. Annals of Emergency Medicine, 33(1), pp.67-72. Available at: http://dx.doi.org/10.1016/s0196-0644(99)70419-1.

Risposte Tourismo, 2017. Adriatic Sea Tourism Report 2017. Available at: http://www.adriaticseaforum.com/2017/Public/RisposteTurismo_ AdriaticSeaTourismReport2017.pdf, accessed on: Jan 282018.

SSchutz, L., Zak, D. \& Holmes, J.F., 2014. Pattern of Passenger Injury and IIIness on Expedition Cruise Ships to Antarctica. Journal of Travel Medicine, 21(4), pp. 228-234.
Available at:

http://dx.doi.org/10.1111/jtm.12126.

Stupalo, V., Jugović, A. and Mrvica, A., 2016. Kvantitativna analiza pomorskog putničkog prometa u Europi. Naše more, 63(4), pp. 256-263. Available at: http://dx.doi.org/10.17818/nm/2016/4.2.

Vallé, B., Camelot, D., Bounes, V., Parant, M., Battefort, F., Ducassé, J.L. and Pujos, M., 2010. Cardiovascular diseases and electrocardiogram teletransmission aboard ships: the French TMAS experience. Int. Marit. Health, 62(3), pp. 129-136.

Westlund, K. et al., 2016. Telemedical Maritime Assistance Service (TMAS) to Swedish merchant and passengers ships 1997-2012. International Maritime Health, 67(1), pp. 24-30. Available at:

http://dx.doi.org/10.5603/imh.2016.0006. 